\title{
PENINGKATAN PENGETAHUAN PBHS DAN PENERAPAN CUCI TANGAN DALAM UPAYA PENCEGAHAN COVID-19 PADA SANTRI DI LINGKUNGAN PONDOK PESANTREN
}

\author{
W Wahyuni ${ }^{1)}$, Siti fatmawati ${ }^{2)}$ \\ ${ }^{1}$ Program Studi Sarjana Keperawatan, Fakultas Ilmu Kesehatan \\ Universitas Aisyiyah Surakarta \\ ${ }^{2}$ Program Studi D3 Keperawatan, FakultasIlmu Kesehatan \\ Universitas Universitas Aisyiyah Surakarta \\ E-mail :yunyskh@gmail.com
}

\begin{abstract}
Pondok Pesantren is one of the educational places in Indonesia where students live together. In almost all cities you can find Islamic boarding schools with various problems., an unhealthy environment is closely related to an increased incidence of disease. Especially with the Covid-19 pandemic, one of the behaviors that must be carried out by Pondok santri is to wash their hands with running water with soap in the hope that students can increase their knowledge of washing hands and apply it in their daily behavior in preventing Covid-19. In addition to the factor of hand washing habits that are not frequently practiced, there are also other factors that influence health behavior, namely the lack of health promotion regarding hand washing. The aim of this activity is to promote how to wash hands with soap for the prevention of Covid-19. The method in this activity is giving lectures, direct questions and answers, demonstrations of washing hands with soap, redemonstrations by students, the results of previous knowledge of washing hands 24 (34.2)\% to 48 (68.8\%). In conclusion there is an increase in knowledge of washing hands with soap
\end{abstract}

Keywords : Hand Washing; Knowledge; Covid-19; Prevention, PBHS

\section{PENDAHULUAN}

Pondok Pesantren merupakan salah satu bentuk lembaga pendidikan keagamaan yang tumbuh dan berkembang dari oleh dan untuk masyarakat yang berperan penting dalam pengembangan sumber daya manusia, diharapkan para santri dan para pemimpin serta pengelola pondok pesantren tidak saja mahir dalam aspek pembangunan moral dan spiritual dengan intelektual yang bernuansa agamis, namun dapat pula menjadi penggerak motivator dan inovator dalam pembangunan kesehatan, serta menjadi teladan dalam berperilaku hidup bersih dan sehat bagi masyarakat sekitar. Dalam masa pandemic yang melanda Indonesia sejak bulan Januari 


\section{GEMASSIKA: Jurnal Pengabdian Kepada Masyarakat}

Vol. 4 No. 2 November 2020

2020 semua warga masyarakat tidak ketinggalan untuk melakukan pencegahan terhadap virus corona covid-19. Masyarakat warga pondok pesantren khususnya para santriwan dan santriwati telah melakukan beberapa upaya dalam rangka mencapai Perilaku hidup Bersih dan sehat (PBHS). perilaku cuci tangan dengan sabun dan pemakaian masker. Cuci tangan pakai sabun (CTPS) merupakan salah satu indikator output dari strategi nasional STBM (Sanitasi Total Berbasis Masyarakat), yaitu setiap rumah tangga dan sarana pelayanan umum dalam suatu komunitas (seperti sekolah, kantor, rumah makan, puskesmas, pasar, terminal, pondok pesantren ) tersedia fasilitas cuci tangan (air, sabun, sarana cuci tangan), sehingga semua orang mencuci tangan dengan benar (Kementerian Kesehatan RI, 2014) .

Cuci tangan dapat dipengaruhi oleh beberapa faktor diantaranya yaitu pengetahuan dan sikap (Perilaku Notoatmodjo, 2010). Pengetahuan merupakan keluaran dari proses sensoris utamanya mata dan telinga terhadap suatu objek tertentu. Sikap merupakan respons tertutup seseorang terhadap objek atau stimulus yang berasal dari dalam maupun dari luar dan manifestasinya tidak dapat dilihat langsung, namun hanya bisa ditafsirkan oleh perilaku yang tertutup tersebut (Sunaryo, 2014). Pengetahuan dan sikap terhadap cuci tangan dapat mempengaruhi seseorang untuk mau dan mampu melakukan perilaku cuci tangan tersebut.

Mencuci tangan bermanfaat agar tangan menjadi bersih dan dapat membunuh mikroorganisme yang ada di tangan, dan telah dibuktikan dari study terdahulu dapat mencegah penyakit infeksi di masyarakat seperti diare, Infeksi Saluran Pernafasan Atas (ISPA) dan flu burung serta covid-19, walaupun demikian pentingnya perilaku cuci tangan pakai sabun (CTPS) untuk mencegah penyakit-penyakit menular tampaknya masih belum dimengerti masyarakat luas termasuk santri di pondok pesantren serta masih belum banyak dilakukan dalam kehidupan seharihari (Panduan CTPS Depkes RI, 2013 dalam Asda.P 2020).

Studi pendahuluan yang dilakukan pada 5 orang santriwandan 5 orang santriwati di pondok pesantren Barokah didapat hasil bahwa masih terdapat masalah kesehatan yang menjadi permasalahan bagi santri yaitu kurangnya pengetahuan tentang cara mencuci tangan beserta penerapan cuci tangan yang benar untk mencegah covid-19. Sedangkan Penelitian Wahyuni (2014) memfokuskan pada bagaimana PBHS pada masyarakat bukan PHBS pada pondok pesantren. Karena indicator PHBS pada anak sekolah dan indicator PHBS pada masyarakat ada sedikit 
perbedaan oleh adapun tujuan dari kegiatan pengabdian ini untuk mensosialisaikan pengetahuan tentang PHBS dan cara mencuci tangan dengan sabun baik teori maupun prakteknya.

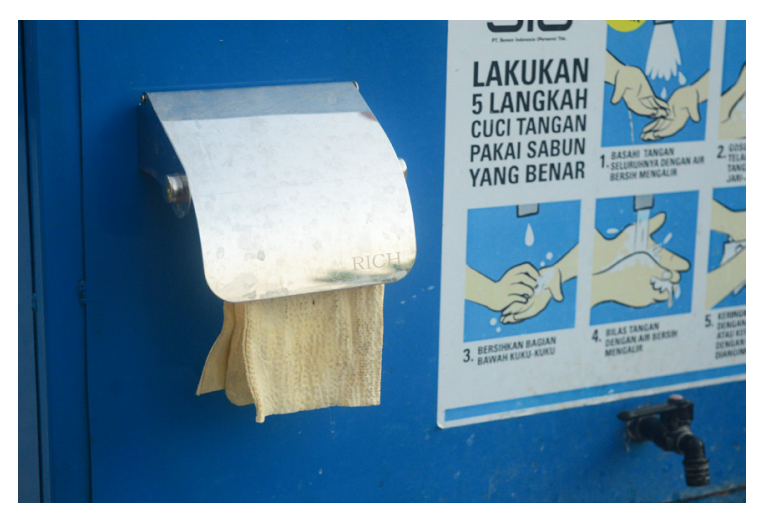

Gambar 1. Langkah-langkah cuci tangan

\section{MASALAH, TARGET DAN LUARAN}

Permasalaan yang dihadapioleh para santri berdasarkan wawancara dengan 5 santriwan dan santriwati bahwa belum mengetahui tentang cuci tangan untuk pencegahan covid -19 dan belum tahu caranya pelaksanaan cuci tangan menggunakan sabun dan air mengalir untuk pencegahan covid-19; target yang diharapkan pada kegiatan ini adalah santriwan dan santriwati mengetahui tentang informasi cuci tangan untuk pencegahan covid-19 dan dapat mempraktekkan cuci tangan pencegahan covid-19. Luaran yang diharapkan terjadi peningkatan pengetahuan maupun peningkatan penerapan cuci tangan dan diharapkan dapat terbit di jurnal terakreditasi sinta

\section{METODE PELAKSANAAN}

Pelaksanaan Program pengabdian Masyarakat ini diawali dengan sosialisasi program pengetahuan dan pencegahan penyakit covid-19 di lokasi Pondok Pesantren dukuh Nandan Rt 1 Rw 5 yang dihadiri oleh ketua pengasuh Pondok pesantren Barokah dan Ketua Santri dan santiwatiwan dan dihadiri oleh ustad atau guru ngaji pondok dan pengurus masjid berdiskusi tentang pelaksanaan program guna memberi masukan sehingga pelaksanan nanti berjalan dengan lancar. Metode yang akan diterapkan dalam kegiatan tersebut dengan Soassialisi/ Ceramah Metode sosialisasi tentang masalah covid-19, cara cuci tangan dengan sabun, PBHS, demonstrasi cuci tangan pada santriwan dan santriwati kemudian cara untuk pengumpulan data dengan menyebarkan angket pre test dan post test untuk menilai pengetahuan sedangangkan untuk menilai praktekknya dengan membuat chek list untuk mengontrol penerapan cuci tangan luaran dari kegiatan ini setelah selesai akan direncanakan untuk dimuat di jurnal ilmiah nasional

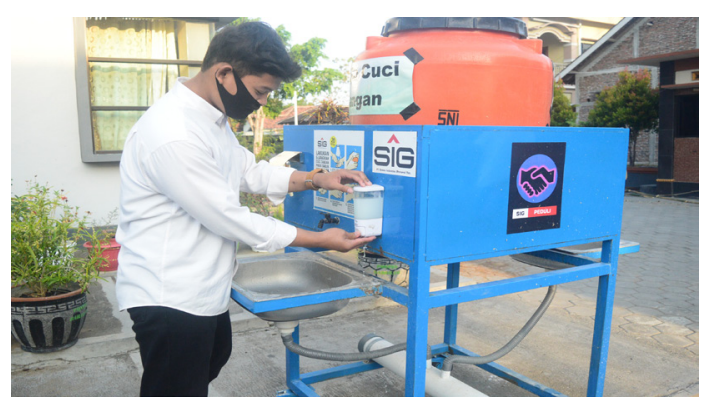

Gambar 2. Santri mempraktikkan cuci tangan 


\section{HASIL PEMBAHASAN}

\section{A. Gambaran Lokasi Pengabdian Masya-} rakat

Pondok pesantren Barokah merupakan salah satu pondok yang berlokasi di kalurahan Sidorejo merupakan salah satu kalurahan yang ada di kecamatan Bendosari kalurahan Sidorejo berada pada perbatasan lokasi, Sebelah barat dibatasi dengan kalurahan Bulakrejo, Sebelah timur dibatasi oleh Kalurahan Toriyo, Sebelah Selatan dibatasi oleh Kalurahan Jombor, Sebelah Utara dibatasi oleh Kalurahan Gentan

\section{B. Karakteristik Responden Pondok Pesantren}

Karakteristik santriwan santri wati Di pondok pesantren barokah kalurahan Sidorejo terlihat di table 1

Tabel 1. Distribusi Frekuensi Responden Berdasarkan Umur Santri

\begin{tabular}{cccc}
\hline No & Pengetahuan & Pre test & Post test \\
\hline 1. & $>20$ tahun & 50 & 71.5 \\
2. & $<20$ tahun & 20 & 28.5 \\
& & & \\
\hline & Jumlah & 70 & 70 \\
& & & $(100 \%)$ \\
\hline
\end{tabular}

Sumber : Data Primer Bulan April Tahun 2020
Berdasarkan tabel 1 dapat diketahui bahwa sebagian besar responden berumur $<20$ tahun dengan jumlah 50 santri $(71,5 \%)$.

Tabel 2. Distribusi Frekuensi Responden

Berdasarkan Jenis Kelamin Santri

\begin{tabular}{llll}
\hline No & $\begin{array}{c}\text { Jenis } \\
\text { kelamin }\end{array}$ & Jumlah & Prosentase \\
\hline 1. & Laki-laki & 25 & 35.7 \\
2. & Perempuan & 45 & 64.5 \\
\hline & Jumlah & 70 & $(100 \%)$ \\
\hline
\end{tabular}

Sumber : Data Primer Bulan April Tahun 2020

Berdasarkan tabel 2, dapat diketahui bahwa responden adalah laki-laki 25 (35.7\%) dan perempuan 45 (64.3\%). Jenis kelamin dapat membedakan perilaku dan karasteristik hasil dari perilaku (Notoatmodjo: 2010) Tingkat pendidikan akan mempengaruhi pengetahuan mengenai perilaku hidup bersih dan sehat. Individu yang tingkat pendidikannya lebih tinggi akan lebih mampu mengaplikasikan perilaku hidup bersih dan sehat, namun bukan berarti seseorang yang tingkat pendidikannya lebih rendah akan mempunyai pengetahuan yang rendah 
Tabel 3. Distribusi Frekuensi Responden Berdasarkan Pendidikan Santri

\begin{tabular}{llll}
\hline No & Pendidikan & Jumlah & Prosentase \\
\hline 1. & SMA & 59 & 84.2 \\
2. & SMP & 11 & 15.8 \\
\hline & Jumlah & 70 & $(100 \%)$ \\
\hline
\end{tabular}

Sumber : Data Primer Bulan April Tahun 2020

Berdasarkan tabel 3, dapat diketahui bahwa sebagian besar responden adalah berpendidikan SMA 59 (84.2) .Karasteristik pendidikan responden disini adalah SMU atau sederajat. Responden yang terbanyak dari keseluruhan adalah SMU kelas 2. Pengetahuan itu sendiri dipengaruhi oleh pendidikan. Semakin tinggi tingkat pendidikan seseorang, maka semakin mudah menerima informasi sehingga makin banyak pula pengetahuan yang diterima (Wawan, A. 2010). Peneliti berpendapat bahwa individu yang berpendidikan lebih tinggi dapat berperilaku lebih baik dari pada yang berpendidikan yang lebih rendah. respon seseorang terhadap suatu hal dipengaruhi oleh tingkat pendidikan. Pada individu dengan pendidikan tinggi akan memberikan respon yang logis terhadap informasi yang datang dan akan berpikir sejauh mana pengaruh yang diperoleh. Mubarak (2012) mengungkapkan bahwa tidak dapat dipungkiri bahwa semakin mudah seseorang memahami informasi dipengaruhi oleh tingkat pendidikan serta semakin bertambah pula informasi yang diketahui dan sebaliknya.

Hasil Sosialisasi pengetahuan tentang materi PHBS di dapatkan hasil sebagai berikut:

Tabel 4. Hasil pre test dan post test materi pengetahuan PBHS pada 70 orang pada santri di pondok pesantren

\begin{tabular}{llll}
\hline No & Pengetahuan & Pre test & Post test \\
\hline 1. & Tinggi & $12(20 \%)$ & $58(82.85 \%)$ \\
2. & Sedang & $28(46.6 \%)$ & $10(16.6 \%)$ \\
3. & Rendah & $30(42.85)$ & $2(3.4 \%)$ \\
\hline & Jumlah & $70(100 \%)$ & $70(100 \%)$ \\
\hline
\end{tabular}

Sumber : Data Primer Bulan April Tahun 2020

Berdasarkan table 4 menunjukkan sebagian besar responden sebelum dilakukan sosialisasiyang berpengetahuan tinggi hanya 12 orang (20\%) setelah dilakukan sosialisasi terjadi peningkatan menjadi 58 orang $(82.85 \%)$ sedangkan yang berpengetahuan rendah sebelum dilakukan sosialisasi ada 30 orang (42.85\%) setelah dilakukan sosialisasi menjadi 2 orang $(3.4 \%)$.

Perilaku Hidup Bersih dan Sehat (PHBS) adalah upaya peningkatan 
pengetahuan kesadaran, kemampuan, dan kemauan untuk berperilaku hdup bersih dan sehat bagi pribadi, keluarga dan masyarakat umum yang minimal dapat memberikan dampak bermakna terhadap kesehatan dan meningkatkan sumber daya pola manusia khususnya dalam peningkatan derajat kesehatan, status gizi, hidup, dan pemanfaatan kesetahan lingkungan agar tercapai derajat kesehatan yang optimal (Mubarak, 2012). Penatalaksanaan PHBS dilakukan pada setiap kegiatan rumah tangga, sekolah/ pesantren, tempat kerja, (institusi/sarana kesehatan), tempat-tempat umum, organisasi/lembaga kemasyarakatan, dan lain-lain (Mubarak, 2012). Perilaku hidup bersih dan sehat (PHBS) santri yang sudah baik yaitu, selalu mencuci tangan sebelum makan dan setelah buang air besar serta tidak ada santri yang pernah menggunakan narkoba, sementara PHBS santri yang kurang yakni tindakan menghindari penularan penyakit. Diharapkan pengasuh pondok pesantren rutin mengontrol kebersihan dan kesehatan santri untuk mengurangi risiko penularan penyakit.( Rizka, 2015)

Hasil Sosialisasi pengetahuan tentang materi cuci tangan di dapatkan hasil sebagai berikut:
Tabel 5. Hasil pre test dan post test materi pengetahuan cuci tangan pada 70 orang pada santri di ponpes barokah

\begin{tabular}{llll}
\hline No & $\begin{array}{l}\text { Peng. } \\
\text { cuci tangan }\end{array}$ & Pre test & Post test \\
\hline 1. & Tinggi & $\begin{array}{l}24 \\
(34.2 \%)\end{array}$ & $48(68.6 \%)$ \\
& & 26 & $20(28.57 \%)$ \\
2. & Sedang & $\begin{array}{l}26 \% \\
(37.1 .0 \%)\end{array}$ \\
3. & Rendah & $20(28.5)$ & $2(2.8 \%)$ \\
\hline & Jumlah & $70(100 \%)$ & $70(100 \%)$ \\
\hline
\end{tabular}

Sumber : Data Primer Bulan April Tahun 2020

Berdasarkan table 5 menunjukkan sebagian besar responden sebelum dilakukan sosialisasi yang berpengetahuan tinggi hanya 24 orang (34.2\%) setelah dilakukan sosialisasi terjadi peningkatan menjadi 48 orang $(68.6 \%)$ sedangkan yang berpengetahuan rendah sebelum dilakukan sosialisasi ada 20 orang (28.5\%) setelah dilakukan sosialisasi menjadi 2 orang $(2.8 \%)$. Sesuai hasil penelitian Srisantyorini,T. et all (2020) .didapatkan hasil bahwa sebagaina besar santri $(64,1 \%)$ mempunyai kebiasaan selalu mencuci tangan pakai sabun. Berbeda dengan hasil penelitian Purnama,T,B et all ( 2020) bahwa Personal Hygiene pada santri masih memiliki perilaku CTPS yang rendah, Perilaku CTPS yang 
tertinggi terdapat di Pondok Pesantren AK dengan presentase 47,9\%. Dikategorikan masih rendah hal ini dikarekan. Pondok pesantren tidak selalu menyediakan tempat untuk mencuci tangan dengan menggunakan sabun selain itu, faktor lain yang mendukung adalah kurangnya pengetahuan santri terkait pentingnya cuci tangan dan peran kebiasaan cuci tangan terhadap timbulnya penyakit

Peneliti berpendapat bahwa pengetahuan cuci bisa ditingkatkan karena adanya sarana dan prasarana yang lebih memadai. Dipandang dari segi kesehatan penggunaan air yang dengan sering mencuci tangan dapat membantu membunuh kuman sehingga penyakit covid-19 tidak akan terjadi sebaliknya jika dipandang dari segi agama penggunaan air semacam itu untuk menghilangkan hadast kecil yang berada di sekitar tempat wudhu atau kamar mandi. Sarana dan prasarana di dalam pondok pesantren yang baik sangat mendukung dan mempermudah terjadinya perilaku hidup bersih dan sehat santri di lingkungan pondok

Berdasarkan hasil penelitian Ade M dan Gustof (2015) Distribusi frekuensi responden berdasarkan PHBS kebiasaan cuci tangan dalam kategori baik sebanyak $60,0 \%$, diketahui bahwa rendahnya perilaku cuci tangan pakai sabun pada santri rata rata disebabkan karena tidak terbiasa menggunakan sabun ketika cuci tangan, terburu-buru, malas, dan lain sebagainya. Perilaku ini dapat terjadi akibat beberapa faktor yang dapat mempengaruhi terbentuknya suatu perilaku yaitu niat dan keinginan, motivasi, dan juga faktor lingkungan termasuk kebiasaan teman atau orangorang disekitar yang dapat berpengaruh pada perilaku individu. Salah satu cara sederhana perilaku hidup bersih dan sehat adalah dengan melakukan cuci tangan pakai sabun untuk meningkatkan kesadaran tentang pemeliharaan kesehatan pribadi. Namun cuci tangan pakai sabun sering dianggap sebagai hal yang sepele di masyarakat tidak terkecuali pada santri yang tinggal dan menetap di Pondok Pesantren. Berdasarkan fenomena yang terjadi, banyak anakanak usia sekolah mempunyai kebiasaan kurangnya memperhatikan perlunya cuci tangan dalam kehidupan sehari-hari. Santri biasanya langsung makan makanan yang disajikan tanpa mencuci tangan pakai sabun terlebih dahulu. Perilaku tersebut tentunya berpengaruh dan dapat memberikan kontribusi dalam terjadinya penularan penyakit. (Purwandari R, A Anisah, Wantiyah. 2013) 
Perilaku mencuci tangan menggunakan sabun setelah $\mathrm{BAB}$ pada responden yang telah baik dapat mengurangi risiko kecacingan (Widoyono, 2011). Hasil penelitian Chadijah dkk. (2014) pada penilaian variabel perilaku anak sekolah dasar di Kota Palu Sulawesi Tengah tahun 2011 tentang kebiasaan mencuci tangan sebelum makan menunjukkan bahwa sebagian besar responden telah mempunyai kebiasaan mencuci tangan sebelum makan dan setelah BAB dengan baik. Terdapat 244 responden telah mempunyai kebiasaan mencuci tangan sebelum makan dan 258 responden untuk kebiasaan mencuci tangan (Chadijah, Sitti, P.P.F. Sumolang, N.N. Veridiana. 2014). .

\section{KESIMPULAN DAN SARAN}

Sebagian besar responden berumur $<20$ tahun (71,5\%)., Sebagian besar berpendidikan SMA 59 (84.2) .Sebagian besar responden sebelum dilakukan sosialisasi materi PHBS yang berpengetahuan tinggi (20\%) meningkat menjadi (82.85\%) sedangkan yang berpengetahuan rendah sebelum dilakukan sosialisasi (42.85\%) setelah di sosialisakan menurun (3.4\%)., Sebagian besar responden sebelum dilakukan sosialisasi materi cuci tangan berpengetahuan tinggi (34.2\%) setelah dilakukan sosialisasi terjadi peningkatan (68.6\%) sedangkan yang berpengetahuan rendah sebelum dilakukan sosialisasi ada (28.5\%) setelah dilakukan sosialisasi turun $(2.8 \%)$ sedangkan menurut penelitian

\section{SARAN}

Dari kesimpulan di atas dapat kita berikan saran dengan kegiatan penyuluhan akan meningkatkan pengetahuan baik pengetahauna tentang cuci tangan dan penerapannya maupun pengetahuan PHBS jadi kegiatan itu harus sering dilkasanakan

\section{DAFTAR PUSTAKA}

Ade M., G, Gustop A., (2015) Perilaku Hidup Bersih Dan Sehat (Phbs) Dalam Upaya Mencegah Penyakit Kulit Pada Santri Di Pondok Pesantren Nurul Huda Jurnal Keperawatan, Volume XI, No. 1, April 2015

Asda.P dan Novita S (2020), Perilaku Cuci Tangan Pakai Sabun (Ctps) Dan Kejadian Penyakit Infeksi Dalam Keluarga Di Wilayah Desa Donoharjo Kabupaten Sleman Jurnal Media Keperawatan: Politeknik Kesehatan Makassar vol 11 no 01 tahun 2020 
Chadijah, Sitti, P.P.F. Sumolang, N.N. Veridiana. 2014. Hubungan, Pengetahuan, Perilaku dan Sanitasi Lingkungan dengan Angka Kecacingan pada Siswa Sekolah Dasar di Kota Palu, Media Litbangkes, Vol. 24 No. 1, Mar 2014, 50-56. )

Kemenkes RI (2012); Profil Kesehatan Indonesia, HEALTH STATISTICS Pusat Data dan Informasi Profil Kesehatan Indonesia 2012, -- Jakarta :

Kementerian Kesehatan RI. 2017.Profil Kesehatan Indonesia. Jakarta: Kementerian Kesehatan RI.

Purnama, T,B. Sri, R, H. Eliandy , C,L, (2020), Perilaku Cuci Tangan Pakai Sabun pada Santri di Pondok Pesantren Kota Medan, Jurnal Promosi Kesehatan Indonesia Vol 15 / No. 2 / Agustus 2020

Notoadmodjo S. (2010) Ilmu Perilaku Kesehatan. Jakarta: Rineka cipta

Purwandari R, AAnisah, Wantiyah.(2013) Hubungan Antara Perilaku Mencuci Tangan Dengan Insiden Diare Pada Anak Usia Sekolah di Kabupaten Jember. J Keperawatan [Internet]. 2013;4(2). Available from: http://ejournal.umm.ac.id/index.php/keperawatan/ar ticle/ view/2362

Rizka; I, Z; (2015) Perilaku Hidup Bersih Dan Sehat Santri Di Pondok Pesantre Mamba'us Syafa'atilqur'an Jurnal Ners dan Kebidanan, Volume 2, Nomor 3, Desember 2015, hlm. $242-247$

Widoyono, 2011.Penyakit Tropis. Epidemiologi, Penularan, Pencegahan dan Pemberantasannya, Penerbit Erlangga, Jakarta

Dwi .S dan Wahyuni (2014) Hubungan Pengetahuan Santriwati Tentang Penyakit Skabies Dengan Perilaku Pencegahan Penyakit Skabies Di Pondok Pesantren GASTER Vol. 11 No. 2 Februari 2014

Sunaryo. 2014. Psikologi Untuk Keperawatan. Jakarta: EGC.

Srisantyorini,T. Suherman, Wulan A. (2020), Pemantauan Karakteristik Kebiasaan Cuci Tangan Sebagai Upaya Pencegahan Hepatitis A Di Pesantren Sabilunnajat Volume. 1 No. 1. Hal. 11-15, AS-SYIFA: Jurnal Pengabdian dan Pemberdayaan Kesehatan Masyarakat 